\title{
Analisis Sistem Kendali Robot USMAN untuk Sterilisasi Lantai Masjid dengan Algoritma Proportional Integral Derivative
}

\author{
Elik Hari Muktafin ${ }^{1}$, Kusrini ${ }^{2}$, Emha Taufiq Luthfi $^{3}$ \\ Magister Teknik Informatika, Universitas Amikom Yogyakarta \\ Yogyakarta, Indonesia \\ e-mail: ${ }^{1}$ elik.muktafin@ @students.amikom.ac.id, ${ }^{2}$ kusrini@amikom.ac.id, ${ }^{3}$ emhataufiqluthfi@ amikom.ac.id
}

Diajukan: 8 Desember 2020; Direvisi: 18 Desember 2020; Diterima: 19 Desember 2020

\begin{abstract}
Abstrak
Lantai masjid merupakan media potensial untuk penyebaran COVID-19. Virus dapat menempel pada lantai dan terhirup oleh jamaah saat melakukan salat, sehingga dibutuhkan alat untuk membantu sterilisasi lantai masjid secara berkala. Dengan robot sterilisasi USMAN yang dilengkapi dengan sinar UVC diharapkan dapat membantu proses sterilisasi secara efektif. Tujuan penelitian ini adalah untuk meningkatkan kinerja sistem kendali robot USMAN dengan penerapan algoritma PID (ProportionalIntegral-Derivative), agar dapat bergerak lurus dan bermanuver secara tepat. Kebaruan penelitian ini adalah penerapan Algoritma PID pada robot sterilisasi dengan ukuran memanjang $100 \mathrm{~cm}$ yang sulit dikendalikan dengan teknik set-timer. Penelitian ini terdiri dari tahapan analisis, desain, pengodean dan pengujian robot. Penggunaan kendali set-timer digantikan Algoritma PID dengan nilai $K_{p}=10, K_{i}=0$ dan $K_{d}=100$ yang dikombinasikan dengan sensor kompas, jarak dan rotary encoder. Hasil pengujian menunjukkan peningkatan kinerja kendali robot USMAN dengan nilai standar deviasi tertinggi untuk ketepatan jarak tempuh dari 10.46 menjadi 0,44, kelurusan gerak dari 10.21 menjadi 0,35 dan manuver berbelok dari 1,80 menjadi 0,29. Pembacaan halangan dengan sensor jarak untuk pengereman otomatis akurat di bawah $70 \mathrm{~cm}$. Proses sterilisasi lantai masjid dengan ukuran $10 \mathrm{~m} \times 10 \mathrm{~m}$ membutuhkan waktu 36,3 menit.
\end{abstract}

Kata kunci: COVID-19, Masjid, UVC, Robot Sterilisasi, PID

\begin{abstract}
Mosque floors are potential medium for the spread of COVID-19. The virus can stick to the floor and be inhaled by worshipers while performing prayers, so a tool is needed to periodically sterilize the floor of the mosque. With the USMAN sterilization robot equipped with UVC ray, it is hoped that it can help the sterilization process effectively. The purpose of this research is to improve the performance of the USMAN robot control system by applying the PID (Proportional-Integral-Derivative) Algorithm, so that it can move straight and maneuver appropriately. The novelty is the application of the PID algorithm to a sterilization robot measuring $100 \mathrm{~cm}$ in length which is difficult to control with the set-timer technique. This research consists of the stages of analysis, design, coding and robot testing. The set-timer control was replaced by the PID algorithm with values of $K p=10, K i=0$ and $K d=100$ combined with compass, distance and rotary encoder sensors. The test results show an increase in the performance of the USMAN robot control system with the highest standard deviation value for distance accuracy from 10.46 to 0.44 , motion straightness from 10.21 to 0.35 and maneuver turning from 1.80 to 0.29 . Obstacle reading with a proximity sensor for automatic braking is accurate under $70 \mathrm{~cm}$. The process of sterilizing the mosque floor with a size of $10 \mathrm{~m} \times 10 \mathrm{~m}$ takes 36.3 minutes.
\end{abstract}

Keywords: COVID-19, Mosque, UVC, Sterilization Robot, PID

\section{Pendahuluan}

SARS-CoV-2 yang lebih dikenal dengan nama virus Corona adalah jenis baru dari Corona virus yang menular ke manusia. Infeksi virus Corona disebut COVID-19 (Corona Virus Disease 2019) pertama kali ditemukan di kota Wuhan, China pada akhir Desember 2019 [1]. Virus ini menular dengan sangat cepat dan telah menyebar ke hampir semua negara, termasuk Indonesia. Di Indonesia telah diberlakukan kebijakan new normal dengan penerapan protokol kesehatan untuk menekan penyebaran virus Corona, sekaligus tetap memberikan ruang kepada masyarakat dalam beraktivitas. 
Berbagai upaya dilakukan sebagai pencegahan penyebaran virus Corona, termasuk dalam kegiatan ibadah. Dalam agama Islam, kegiatan ibadah salat lima waktu diutamakan dengan berjamaah di masjid [2]. Lantai masjid dan alas salat merupakan salah satu media yang berpotensi menyebarkan virus Corona. Transmisi virus Corona dapat melalui benda yang terkontaminasi virus [3]. Virus yang dibawa oleh jamaah sebelumnya dapat menempel pada lantai dan berpotensi terhirup jamaah lain saat melakukan gerakan sujud dalam salat. Membawa sajadah sendiri tidak berarti aman, karena apabila lantai tidak steril, maka virus Corona dapat menempel pada sajadah dan terbawa pulang ke rumah.

Solusi yang paling tepat adalah dengan melakukan sterilisasi lantai masjid dan alas salat secara berkala. Sterilisasi dapat dilakukan dengan memanfaatkan bahan kimia rumah tangga sebagai disinfectant maupun menggunakan radiasi sinar UVC (Ultraviolet-C) [4]. Sinar UVC adalah sinar dengan panjang gelombang $254 \mathrm{~nm}$ yang memiliki sifat germicidal yang dapat membunuh virus, kuman dan bakteri [5]. Penggunaan sinar UVC lebih efektif dibandingkan disinfektan karena tidak meninggalkan residu, tetapi dalam penggunaannya perlu berhati-hati karena sinar UVC tidak boleh terpapar langsung ke manusia [6]. Penelitian sebelumnya oleh dokter Anthony Griffiths, menunjukan sinar UVC dapat menonaktifkan 99\% virus Corona dengan dosis $5 \mathrm{~mJ} / \mathrm{cm} 2$ dalam waktu 6 detik [7]. Untuk dapat mencapai nilai germicidal minimum yang dapat membunuh virus Corona setiap bagian lantai masjid harus terpapar sinar UVC dengan dosis dan lama waktu penyinaran yang tepat [5].

Dibutuhkan teknik sterilisasi yang tepat dan efisien karena kegiatan sterilisasi harus dilakukan berulang dan membutuhkan waktu dalam prosesnya, solusinya adalah menggunakan robot untuk meringankan kerja manusia [8]. Kebaruan inovasi yang kami hadirkan adalah penggunaan robot beroda untuk membantu proses sterilisasi lantai masjid, kami mengembangkan robot bernama USMAN (UVC Sterilizer Lantai Masjid yang Aman). USMAN dilengkapi dengan sistem microcontroller yang dapat dikendalikan secara manual maupun secara otomatis. USMAN dilengkapi dengan lampu UVC yang ditempatkan pada bagian bawah secara menyamping dan dilengkapi dengan reflektor yang mengarahkan sinar UVC ke lantai agar tidak terpapar ke manusia di sekitar robot. Untuk dapat membunuh virus, kuman dan bakteri secara menyeluruh, robot harus berjalan lurus dengan kecepatan yang stabil dan dapat bermanuver dengan baik sehingga tidak ada bagian lantai masjid yang terlewatkan.

Penelitian sebelumnya tentang robot beroda telah dilakukan oleh Marfanri Lamatenggo tentang penerapan Algoritma PID (Proportional-Integral-Derivative) pada robot keseimbangan beroda dua dengan nilai $K_{p}=60, K_{i}=2.0$, dan $K_{d}=130$. Fungsi Algoritma PID dalam robot ini untuk menjaga keseimbangan robot [9]. Pada penelitian lain oleh Manullang mengendalikan robot dengan Inverse Kinematics dengan rata-rata nilai galat sebesar 0.9 meter, penelitian ini menggunakan Global Positioning System (GPS) sebagai penentu posisi robot yang lebih cocok digunakan di luar ruangan [10]. Penelitian lain oleh Farros Zuhri Ramdhani menggunakan sinar UVC untuk sterilisasi alat makan berbasis microcontroller dengan waktu sterilisasi 15 menit dengan lampu UVC 25 watt dan jarak $10 \mathrm{~cm}$ dari objek [11]. Penelitian tentang robot sterilisasi berbasis UVC juga dilakukan oleh Guettari yang berbentuk robot beroda dengan lampu UVC berdiri di bagian atas untuk sterilisasi ruangan, penggunaan robot ini mengharuskan tidak boleh ada manusia di dalam ruangan agar tidak terkena radiasi UVC [12].

Tujuan penelitian ini adalah untuk menguji dan menganalisis peningkatan kinerja sistem kendali robot USMAN dengan menerapkan Algoritma PID (Proportional-Integral-Derivative) menggantikan sistem kendali konvensional set-timer. Kebaruan pada penelitian ini adalah penerapan Algoritma PID untuk sistem kendali robot sterilisasi lantai masjid dengan sinar UVC, yang memiliki ukuran memanjang $100 \mathrm{~cm}$ dengan 2 roda penggerak. Ukuran robot yang memanjang membuat robot sulit dikendalikan, sehingga penerapan Algoritma PID dibutuhkan agar robot dapat bergerak lurus dan bermanuver secara tepat, agar tidak ada bagian lantai masjid yang terlewat. Pengujian dilakukan pada fungsi aplikasi USMAN, dilanjutkan dengan pengujian kendali gerakan robot yaitu ketepatan jarak tempuh, kelurusan gerak dan manuver berbelok dari robot USMAN, serta akurasi pembacaan halangan dengan sensor jarak untuk fitur pengereman otomatis. Tujuan lain dari penelitian ini adalah untuk menghitung waktu yang dibutuhkan untuk melakukan sterilisasi lantai masjid, agar pengguna dapat menentukan waktu mulai sterilisasi sehingga dapat selesai sebelum memasuki waktu salat.

\section{Metode Penelitian}

Alur penelitian dalam analisis sistem kendali robot USMAN untuk sterilisasi lantai masjid dengan Algoritma PID ditunjukkan pada Gambar 1. 


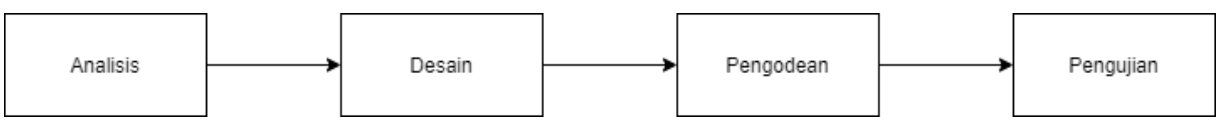

Gambar 1. Metode penelitian

\subsection{Analisis Kebutuhan}

Pada tahapan ini dilakukan analisis kebutuhan fungsional dan non fungsional. Dilakukan wawancara kepada 5 marbut masjid dan tinjauan literatur untuk penggunaan sinar UVC agar mendapatkan kebutuhan fungsional yang perlu diterapkan. Robot sterilisasi dapat dikendalikan secara manual dengan remote dan dapat bekerja secara otomatis, agar dapat disesuaikan dengan bentuk bidang lantai masjid di Indonesia, sebab ada sebagian masjid yang memiliki tiang di tengah ruangan [13]. Robot harus dapat bergerak secara lurus dengan kecepatan konstan dan juga dapat bermanuver dengan tepat. Robot juga harus dapat mendeteksi halangan di sekitarnya untuk melakukan pengereman otomatis agar tidak menabrak.

Selanjutnya dilakukan analisis kebutuhan non fungsional, yang terdiri dari software dan hardware. Software yang dibutuhkan untuk membuat sistem robot adalah: Arduino IDE untuk pembuatan aplikasi pada Arduino dan Android Studio untuk pembuatan aplikasi mobile USMAN. Hardware yang diperlukan untuk membuat robot adalah Arduino Uno R3 sebagai microcontroller, dengan control panel menggunakan LCD 20x4, modul I2C, 4 push button untuk navigasi dan 2 switch untuk tombol power robot dan lampu UVC. Sensor yang dibutuhkan adalah 4 sensor ultrasonik HC-SR04 untuk mendeteksi halangan di sekitar robot, 1 sensor kompas GY-BNO055 untuk menjaga kelurusan gerakan, 2 sensor rotary encoder untuk membaca putaran roda. Penggunaan sensor kompas GY-BNO055 lebih efektif dibandingkan dengan sensor kompas lainnya, karena tidak terpengaruh oleh medan magnet dari benda lain [14].

Untuk penggerak robot USMAN menggunakan 2 motor DC dengan driver motor BTS7960. Untuk melakukan koneksi dengan smartphone menggunakan modul bluetooth HC-06 dengan jarak hubung 15 meter tanpa penghalang dan 9 meter dengan penghalang [15]. Untuk daya listrik membutuhkan rechargeable battery $25.000 \mathrm{mAh}$, inverter DC to AC 220 dihubungkan ke trafo untuk menyalakan lampu UVC, relay untuk menyambung dan memutus arus dan charger adaptor. Untuk sterilisasi menggunakan 2 lampu neon UVC 40W, dengan energi radiasi yang dipancarkan 5,6 mJ/cm2. Energi yang dihasilkan lebih dari cukup untuk menonaktifkan 99\% virus Corona dengan dosis $5 \mathrm{~mJ} / \mathrm{cm} 2$ dalam waktu 6 detik [16].

\subsection{Desain}

Proses desain yang dilakukan pada penelitian ini terdiri dari arsitektur rancangan hardware dan flowchart software.

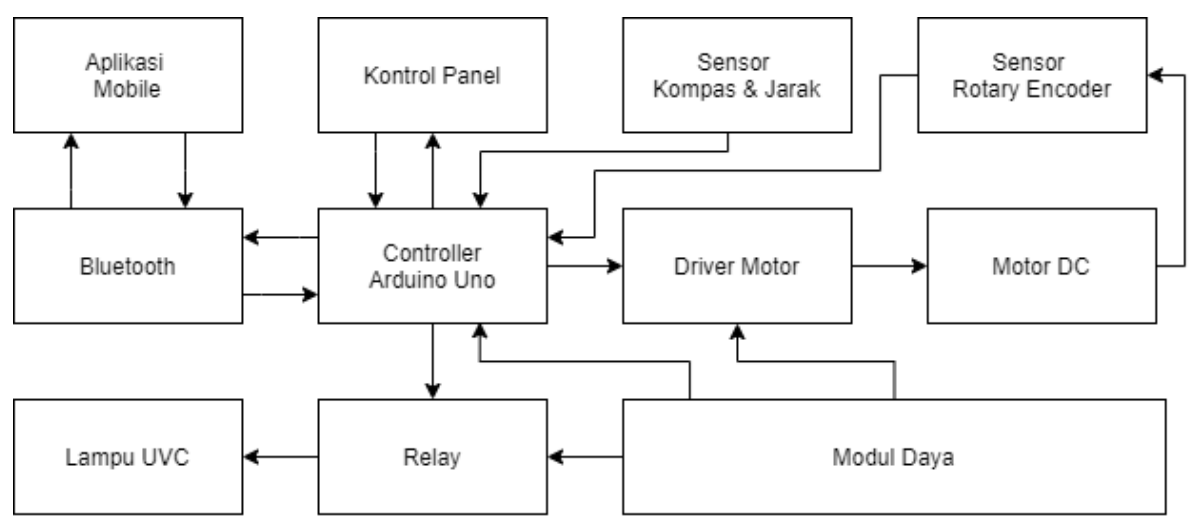

Gambar 2. Desain arsitektur hardware.

Desain hardware pada Gambar 2 menunjukkan modul sensor jarak dan sensor kompas yang terhubung dan mengirimkan data ke controller berupa Arduino Uno. Arduino Uno adalah papan kontrol berbasis microcontroller yang digunakan sebagai pengontrol yang dapat diprogram untuk mengeksekusi instruksi berdasarkan input yang diberikan ke papan [17]. Arduino Uno dapat menerima perintah dari pengguna melalui aplikasi mobile USMAN atau control panel pada robot. Arduino Uno melaksanakan fungsinya sebagai controller dengan menerima data dari sensor, mengolah data lalu mengirim perintah ke driver untuk menggerakkan motor dan relay untuk menyambung atau memutus arus listrik dari modul daya ke lampu UVC. Putaran dari roda dibaca oleh sensor rotary encoder dan dikirim ke controller untuk diolah 
dengan data dari sensor kompas, sehingga robot dapat mengoreksi arah gerakan dan menjaga kelurusan dengan dukungan Algoritma PID [18].

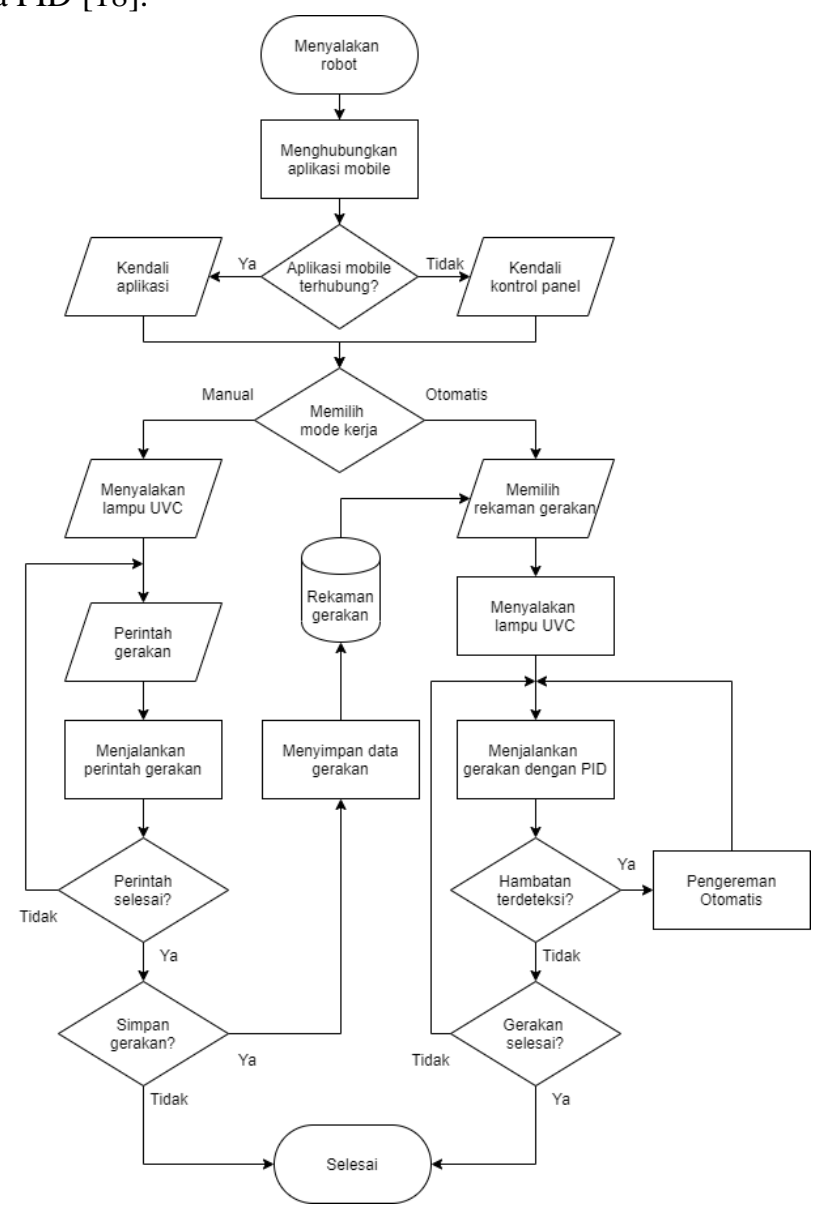

Gambar 3. Desain flowchart sistem.

Gambar 3 menunjukkan alur kerja sistem robot USMAN. Perintah dapat diberikan oleh pengguna melalui aplikasi mobile atau control panel, pengguna dapat menjalankan dua mode perintah yaitu pengendalian manual dan otomatis. Apabila pengguna memilih mode pengendalian manual, maka robot akan melakukan gerakan sesuai perintah gerakan yang ditekan pengguna pada aplikasi mobile. Apabila pengguna memilih mode otomatis, controller akan otomatis menjalankan gerakan yang sudah disimpan sebelumnya. Sistem juga menerima data dari sensor kompas dan sensor rotary encoder untuk diolah menggunakan Algoritma PID dan menghasilkan perintah gerakan pada kedua motor DC, sistem akan melakukan koreksi gerakan secara berulang untuk menjaga agar robot dapat berjalan secara lurus. Apabila sensor jarak mendeteksi ada benda pada jarak $30 \mathrm{~cm}$ di lintasan robot, maka sistem akan menjalankan prosedur pengereman otomatis agar robot tidak menabrak. Sensor jarak mendeteksi jarak benda dengan cara memancarkan gelombang ultrasonik $(40 \mathrm{KHz})$ selama $t=200 \mathrm{us}$ kemudian mendeteksi pantulannya [19].

\subsection{Pengodean}

Pengodean pada penelitian ini menggunakan Android Studio untuk pengembangan aplikasi mobile yang berjalan pada sistem operasi Android dengan bahasa Java, sedangkan untuk aplikasi yang digunakan pada Arduino dibuat dengan Arduino IDE dengan bahasa C. Sistem robot USMAN menerapkan Algoritma PID untuk meningkatkan ketepatan gerakan, kelurusan dan manuver robot agar tidak ada bagian lantai masjid yang terlewatkan. Algoritma PID merupakan penggabungan dari tiga macam pengendali, yaitu pengendali proporsional, pengendali integral, dan pengendali derivative [20]. Algoritma PID digunakan dalam sebuah sistem loop tertutup yang melibatkan umpan balik dari output sistem untuk mencapai respons yang diinginkan [20]. Algoritma PID dapat mengoreksi kesalahan gerakan robot karena faktor hambatan luar seperti roda selip dan lantai bergelombang, sehingga gerakan robot tetap lurus dan stabil. 


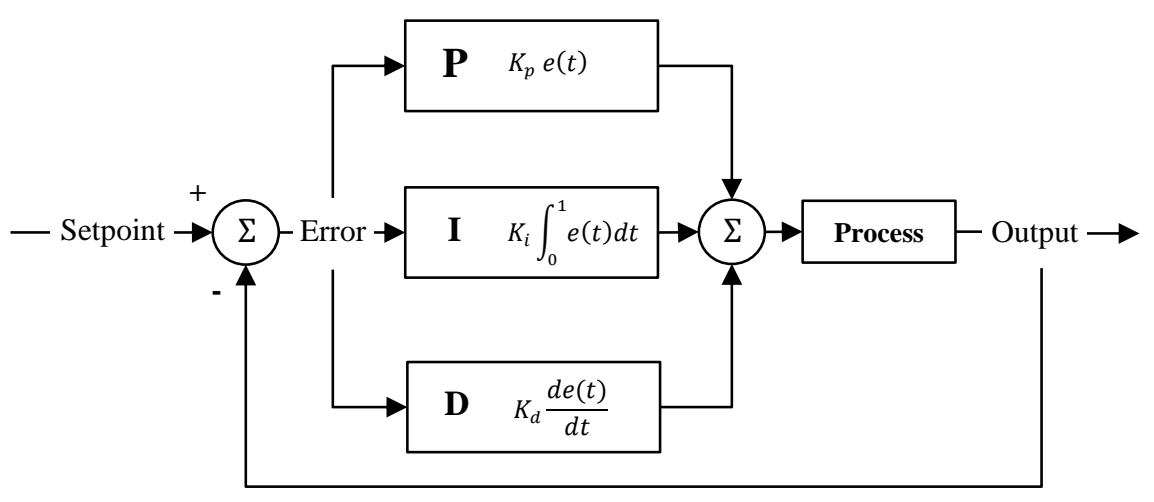

Gambar 4. Diagram alir PID [21].

Dapat dilihat pada Gambar 4, Algoritma PID menggunakan hasil output sebagai feedback untuk diolah kembali dan dicocokkan dengan set point yang ingin dicapai. Ketiga parameter PID dapat dijumlahkan sehingga kendali PID dapat dirumuskan dengan Persamaan 1:

$$
u(t)=K_{p} e(t)+K_{i} \int_{0}^{1} e(t) d t+K_{d} \frac{d e(t)}{d t}
$$

Di mana $u(t)$ adalah sinyal keluaran pengendali PID. $K_{p}$ adalah konstanta proporsional untuk respons pergerakan motor, $K_{i}$ adalah konstanta integral untuk kecepatan akselerasi motor dan $K_{d}$ adalah konstanta derivatif untuk peredam osilasi/bouncing saat motor berputar. Sedangkan $e(t)$ adalah sinyal kesalahan yaitu dari hasil selisih set point dan output yang terjadi [21].

\subsection{Pengujian}

Pengujian yang dilakukan adalah pengujian fungsionalitas aplikasi untuk mengetahui fungsi aplikasi USMAN, dilanjutkan dengan pengujian kendali gerakan dengan dan tanpa penerapan Algoritma PID untuk mengetahui dampak peningkatan kinerja robot. Pengujian yang dilakukan berupa pengujian ketepatan jarak tempuh, ketepatan kelurusan berjalan dan ketepatan manuver berbelok. Penerapan Algoritma PID dalam penelitian ini menggunakan nilai $K_{p}=10, K_{i}=0$ dan $K_{d}=100$. Kemudian dilakukan pengujian jarak pendeteksi halangan yang optimal untuk mendukung fungsi pengereman otomatis. Dilakukan pula perhitungan waktu yang dibutuhkan oleh robot USMAN dalam proses sterilisasi sesuai luasan bidang lantai masjid.

Pengujian dilakukan dalam beberapa kali uji coba untuk mendapat beberapa data. Pengolahan data dalam penelitian ini menggunakan metode standar deviasi. Standar deviasi adalah pengukuran sebaran data yang digunakan untuk mengetahui homogenitas suatu kelompok data atau menentukan sebaran data dalam suatu sampel dan seberapa dekat suatu titik data dengan garis data nilai rata-rata [22]. Semakin besar nilai distribusi standar deviasi berarti variasi nilai datanya semakin besar. Rumus penghitungan standar deviasi ditunjukkan pada Persamaan 2.

$$
S=\sqrt{\frac{n \sum_{i=1}^{n} x_{i}^{2}-\left(\sum_{i=1}^{n} x_{i}\right)^{2}}{n(n-1)}}
$$

Di mana $s$ adalah nilai standar deviasi, sedangkan $x_{i}$ adalah nilai $x$ ke- $i$ dan $n$ adalah ukuran sampel [22].

\section{Hasil dan Pembahasan}

\subsection{Tampilan Hardware}

Hardware dalam penelitian ini berbentuk robot beroda dengan body berukuran panjang $125 \mathrm{~cm}$, lebar $25 \mathrm{~cm}$ dan tinggi $30 \mathrm{~cm}$. Robot dilengkapi dengan 2 roda penggerak yang dipasang di bagian depan di setiap ujung robot, dengan dukungan 2 roda bebas di bagian belakangnya untuk memudahkan pergerakan robot dalam bermanuver. 

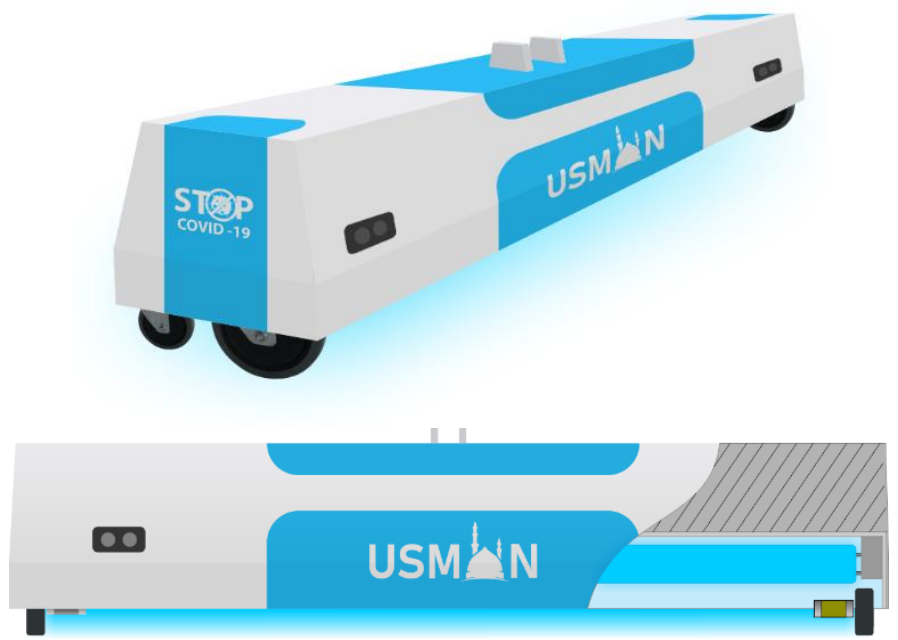

Gambar 5. Tampilan hardware robot.

Gambar 5 menunjukkan tampilan hardware dari robot USMAN dengan casing dan kerangka dari bahan aluminium. Lampu UVC ditempatkan di bagian dalam robot sebelah bawah sedekat mungkin dengan lantai agar menjaga energi radiasi sinar UVC yang diterima permukaan lantai. Lampu UVC ditutup oleh reflektor pada bagian atas dan samping yang berfungsi memantulkan sinar UVC sehingga hanya mengarah ke bawah dan tidak terpapar pada orang di sekitar. Control panel diletakkan di bagian atas dan sensor jarak diletakkan sejumlah 2 buah di depan dan 2 buah di belakang. Untuk peralatan elektronik lainnya dan modul daya diletakkan di dalam body robot.

\subsection{Tampilan Software}

Software yang digunakan terdiri dari aplikasi mobile yang di jalankan pada smartphone Android dan aplikasi yang dijalankan pada Arduino.

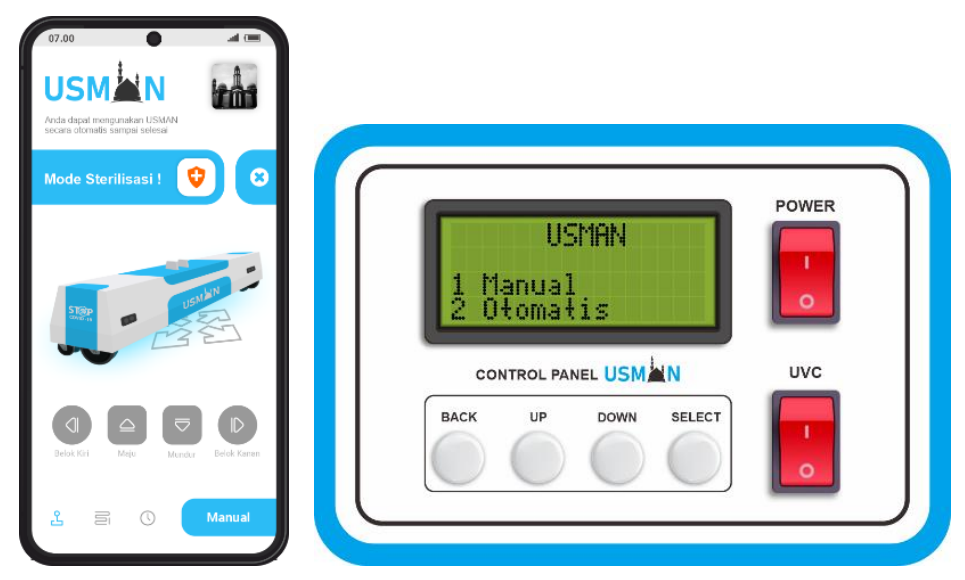

Gambar 6. Tampilan software.

Gambar 6 menunjukkan tampilan aplikasi mobile di sebelah kiri dan tampilan aplikasi pada control panel di sebelah kanan. Pengguna dapat menghubungkan aplikasi mobile dengan robot menggunakan bluetooth. Robot juga dapat dikendalikan dengan control panel yang berada di atas robot dengan 4 tombol navigasi, control panel dapat digunakan untuk menggantikan ketersediaan aplikasi mobile. Robot USMAN dapat dikendalikan dengan pilihan mode manual dan mode otomatis. Mode manual digunakan untuk memindahkan robot atau sterilisasi tempat yang sempit, sedangkan mode otomatis dapat digunakan untuk sterilisasi bagian utama lantai masjid yang mempunyai ukuran yang luas. Mode otomatis bekerja dengan cara pengguna melakukan perekaman gerakan sesuai dengan keadaan bidang lantai masjid dan robot mengulangi gerakan tersebut secara otomatis. 


\subsection{Fungsionalitas Aplikasi}

Pengujian fungsionalitas dilakukan pada aplikasi USMAN. Pengujian mengacu pada metode Black-box ISO 9126-2 dengan faktor kualitas functionality dengan sub faktornya kualitas suitability [23]. Terdapat tiga matriks dalam sub faktor ini yaitu Functional Adequacy, Functional Implementation Coverage, dan Functional Implementation Completeness. Dilakukan 5 test case terhadap fitur pada aplikasi USMAN. Rentang nilai pada standar ISO 9126-2 yaitu 0-1 dengan nilai 0 dinyatakan tidak baik dan nilai mendekati atau sama dengan 1 dinyatakan baik $(0<=X<=1)$. Hasil pengujian aplikasi USMAN menunjukkan semua fungsi berjalan dengan baik seperti ditunjukkan pada Tabel 1.

Tabel 1. Hasil pengujian fungsionalitas.

\begin{tabular}{cccc}
\hline Fitur & FA & FIC & FICM \\
\hline Terhubung ke Robot & 1 & 1 & 1 \\
\hline Kontrol Gerakan Maju & 1 & 1 & 1 \\
\hline Kontrol Gerakan Mundur & 1 & 1 & 1 \\
\hline Kontrol Gerakan Belok Kanan & 1 & 1 & 1 \\
\hline Kontrol Gerakan Belok Kiri & 1 & 1 & 1 \\
\hline Rekam Gerakan & 1 & 1 & 1 \\
\hline Menjalankan Rekaman & 1 & 1 & 1 \\
\hline Atur Jadwal & 1 & 1 & 1 \\
\hline
\end{tabular}

Dari Tabel 1 menunjukkan bahwa fungsi aplikasi USMAN dapat bekerja dengan baik. Aplikasi pada robot USMAN dan aplikasi mobile USMAN dapat terhubung dengan bluetooth. Fungsi kontrol gerakan manual seperti maju, mundur dan berbelok dapat berjalan baik. Fungsi merekam gerakan robot sesuai dengan keadaan ruangan masjid dan fungsi menjalankan rekaman gerakan dapat berjalan baik. Jadwal kerja robot USMAN dapat diatur untuk memulai proses sterilisasi sesuai waktu yang diinginkan.

\subsection{Pengujian Kendali Gerakan}

Pengujian kendali gerakan dilakukan dengan cara melakukan beberapa kali test case dan menganalisis hasilnya. Pengujian jarak tempuh robot dilakukan dengan membandingkan jarak tempuh yang direncanakan pada set point dengan jarak tempuh sebenarnya. Masing-masing variasi jarak dilakukan pengujian sebanyak 3 kali dengan menggunakan Algoritma PID dengan sensor rotary encoder dan sensor kompas serta hanya menggunakan teknik set-timer. Hasil pengujian ditunjukkan pada Tabel 2.

Tabel 2. Hasil pengujian jarak tempuh sebenarnya dibanding set point.

\begin{tabular}{|c|c|c|c|c|c|c|}
\hline \multirow{2}{*}{$\begin{array}{c}\text { Jarak } \\
\text { Tempuh }(\mathbf{c m}) \\
\end{array}$} & \multirow{2}{*}{ Teknik } & \multicolumn{3}{|c|}{ Hasil Jarak Tempuh (cm) } & \multirow{2}{*}{$\begin{array}{l}\text { Rata- } \\
\text { Rata }\end{array}$} & \multirow{2}{*}{$\begin{array}{l}\text { Standar } \\
\text { Deviasi }\end{array}$} \\
\hline & & 1 & 2 & 3 & & \\
\hline 100 & Set-timer & 93.6 & 102.5 & 98.4 & 98.17 & 4.45 \\
\hline 250 & Set-timer & 258.6 & 247.2 & 252.5 & 252.77 & 5.70 \\
\hline 500 & Set-timer & 504.5 & 507.2 & 493.5 & 501.73 & 7.26 \\
\hline 750 & Set-timer & 760.1 & 753.5 & 741.5 & 751.70 & 9.43 \\
\hline 1000 & Set-timer & 1010.5 & 995.4 & 1015.5 & 1007.13 & 10.46 \\
\hline 100 & PID + Rotary + Kompas & 100.1 & 100.3 & 100.4 & 100.27 & 0.15 \\
\hline 250 & PID + Rotary + Kompas & 250.6 & 250.8 & 250.4 & 250.60 & 0.20 \\
\hline 500 & PID + Rotary + Kompas & 500.9 & 501.2 & 501.5 & 501.20 & 0.30 \\
\hline 750 & PID + Rotary + Kompas & 751.1 & 750.8 & 751.5 & 751.13 & 0.35 \\
\hline 1000 & PID + Rotary + Kompas & 1002.5 & 1002.4 & 1003.2 & 1002.70 & 0.44 \\
\hline
\end{tabular}

Dari Tabel 2 diketahui semakin panjang jarak tempuh robot maka semakin besar kesalahan yang terjadi, ditunjukkan dengan selisih antara rata-rata jarak tempuh sebenarnya dengan yang direncanakan. Nilai standar deviasi juga semakin meningkat pada jarak tempuh yang semakin jauh, menggambarkan sebaran hasil yang semakin bervariasi. Tetapi penggunaan Algoritma PID dengan rotary encoder dan sensor kompas menunjukkan hasil kesalahan jarak tempuh yang lebih kecil dibandingkan hanya menggunakan teknik set-timer. Algoritma PID berfungsi untuk mengoreksi posisi robot berdasarkan besar error yang diperoleh, sehingga robot dapat mengoreksi kesalahan posisi robot untuk semakin dekat ke set point [18]. Algoritma PID dapat mengendalikan gerakan robot lebih tepat, dengan selisih kesalahan terbesar hanya $3,2 \mathrm{~cm}$ dengan standar deviasi terbesar 0,44 pada jarak tempuh $1.000 \mathrm{~cm}$. Sedangkan teknik set-timer menunjukkan selisih kesalahan terbesar mencapai $15.5 \mathrm{~cm}$ dengan standar deviasi terbesar 10.46 pada jarak tempuh yang sama. 
Pengujian kelurusan gerakan robot dilakukan dengan menghitung selisih jarak posisi hasil akhir gerakan robot dengan garis lurus ditarik dari titik awal gerakan. Pengujian dilakukan sebanyak 3 kali dengan 5 variasi jarak tempuh yang membandingkan gerakan robot dengan dan tanpa penerapan Algoritma PID dengan rotary encoder dan kompas. Hasil pengujian ditunjukkan pada Tabel 3.

Tabel 3. Hasil pengujian kelurusan gerakan robot.

\begin{tabular}{|c|c|c|c|c|c|c|}
\hline \multirow{2}{*}{$\begin{array}{c}\text { Jarak } \\
\text { Tempuh }(\mathbf{c m})\end{array}$} & \multirow{2}{*}{ Teknik } & \multicolumn{3}{|c|}{ Hasil Jarak Tempuh (cm) } & \multirow{2}{*}{$\begin{array}{l}\text { Rata- } \\
\text { Rata }\end{array}$} & \multirow{2}{*}{$\begin{array}{c}\text { Standar } \\
\text { Deviasi }\end{array}$} \\
\hline & & 1 & 2 & 3 & & \\
\hline 100 & Set-timer & 3 & 5 & 5.5 & 4.50 & 1.32 \\
\hline 250 & Set-timer & 5 & 5.5 & 9 & 6.50 & 2.18 \\
\hline 500 & Set-timer & 10.5 & 8 & 13 & 10.50 & 2.50 \\
\hline 750 & Set-timer & 14.5 & 11 & 20 & 15.17 & 4.54 \\
\hline 1000 & Set-timer & 20.5 & 35.5 & 40 & 32.00 & 10.21 \\
\hline 100 & PID + Rotary + Kompas & 0.5 & 1 & 0.7 & 0.73 & 0.25 \\
\hline 250 & PID + Rotary + Kompas & 1.2 & 1.2 & 0.8 & 1.07 & 0.23 \\
\hline 500 & PID + Rotary + Kompas & 1.5 & 0.9 & 1.4 & 1.27 & 0.32 \\
\hline 750 & PID + Rotary + Kompas & 1.5 & 1.2 & 1.7 & 1.47 & 0.25 \\
\hline 1000 & PID + Rotary + Kompas & 2.2 & 1.8 & 1.5 & 1.83 & 0.35 \\
\hline
\end{tabular}

Dari Tabel 3 diketahui bahwa gerakan robot tanpa Algoritma PID menujukan semakin jauh jarak yang ditempuh robot semakin melenceng dari garis lurus atau set point. Selisih posisi dari garis lurus terbesar mencapai $40 \mathrm{~cm}$, dengan standar deviasi tertinggi mencapai 10.21 yang menunjukkan gerakan robot tidak stabil karena lantai bergelombang dan roda selip. Penerapan Algoritma PID menujukan hasil pergerakan robot yang stabil pada jarak tempuh jauh maupun dekat, dengan selisih posisi dari garis lurus terbesar hanya 2,2 cm dengan standar deviasi terbesar 0,35. Algoritma PID berhasil membuat gerakan robot menjadi stabil, karena setiap gerakan yang salah langsung dikoreksi kelurusannya [18]. Algoritma PID bekerja dengan membaca arah gerakan robot melalui sensor kompas dan apabila terjadi kesalahan gerakan yang diakibatkan oleh lantai bergelombang maupun roda selip. Error yang terjadi langsung direspons oleh Algoritma PID dengan melakukan gerakan untuk mengoreksi posisi dan arah gerak robot sesuai set point pada sensor kompas. Jarak tempuh robot tidak terlalu berpengaruh pada robot, karena Algoritma PID bekerja secara terus menerus pada setiap gerakan yang terjadi selama robot berjalan.

Pengujian ketepatan manuver berbelok robot dilakukan dengan menghitung selisih derajat hasil akhir gerakan berbelok robot dari sudut yang direncanakan dan hasil sudut yang sebenarnya. Pengujian dilakukan sebanyak 3 kali dengan 3 variasi sudut belokan dengan dan tanpa penerapan Algoritma PID. Hasil pengujian ditunjukkan pada Tabel 4.

Tabel 4. Hasil pengujian manuver berbelok robot.

\begin{tabular}{|c|c|c|c|c|c|c|}
\hline \multirow{2}{*}{$\begin{array}{c}\text { Sudut } \\
\text { Belok ( }\left(^{\circ}\right)\end{array}$} & \multirow{2}{*}{ Teknik } & \multicolumn{3}{|c|}{ Sudut Hasil Belokan $\left({ }^{\circ}\right)$} & \multirow{2}{*}{$\begin{array}{l}\text { Rata- } \\
\text { Rata }\end{array}$} & \multirow{2}{*}{$\begin{array}{l}\text { Standar } \\
\text { Deviasi }\end{array}$} \\
\hline & & 1 & 2 & 3 & & \\
\hline 45 & Set-timer & 46 & 44 & 44.5 & 44.83 & 1.04 \\
\hline 90 & Set-timer & 89.5 & 90 & 92.5 & 90.67 & 1.61 \\
\hline 180 & Set-timer & 178 & 179 & 181.5 & 179.50 & 1.80 \\
\hline 45 & PID + Rotary + Kompas & 45.5 & 45 & 45 & 45.17 & 0.29 \\
\hline 90 & PID + Rotary + Kompas & 90 & 90.5 & 90.5 & 90.33 & 0.29 \\
\hline 180 & PID + Rotary + Kompas & 180 & 180 & 180.5 & 180.17 & 0.29 \\
\hline
\end{tabular}

Dari Tabel 4 diketahui bahwa manuver gerakan berbelok robot yang menggunakan Algoritma PID dengan sensor rotary encoder dan sensor kompas menghasilkan gerakan yang lebih tepat, ditunjukkan pada standar deviasi yang sama yaitu 0,29 dengan selisih derajat tertinggi hanya $0.5^{\circ}$. Sedangkan dengan teknik set-timer sudut yang dihasilkan memiliki selisih terbesar mencapai $2,5^{\circ}$ dengan standar deviasi terbesar 1,80. Penerapan Algoritma PID dengan sensor rotary encoder dan sensor kompas pada robot USMAN membuat gerakan manuver berbelok robot menjadi lebih baik dibandingkan hanya menggunakan set-timer. Manuver berbelok robot untuk berpindah ke shaft berikutnya adalah faktor penting yang menentukan kelurusan gerakan berikutnya [24]. Posisi akhir gerakan berbelok robot dijadikan sebagai posisi awal gerakan selanjutnya, sehingga apabila posisi akhir berbelok robot melenceng jauh, maka gerakan selanjutnya juga akan melenceng. Kombinasi sensor rotary encoder dan sensor kompas dapat menangani masalah tersebut. 
Pengujian pembacaan jarak benda atau halangan di sekitar robot dilakukan dengan menghitung selisih jarak sebenarnya dengan jarak yang terbaca pada sensor. Pengujian dilakukan sebanyak 3 kali dengan 10 variasi jarak benda. Hasil pengujian ditunjukkan pada Tabel 5.

Tabel 5. Hasil pengujian jarak benda sebenarnya dibanding sensor.

\begin{tabular}{|c|c|c|c|c|c|}
\hline \multirow{2}{*}{$\begin{array}{c}\text { Jarak Benda } \\
(\mathbf{c m})\end{array}$} & \multicolumn{3}{|c|}{ Hasil Baca Jarak Benda (cm) } & \multirow{2}{*}{$\begin{array}{l}\text { Rata- } \\
\text { Rata }\end{array}$} & \multirow{2}{*}{$\begin{array}{c}\text { Standar } \\
\text { Deviasi }\end{array}$} \\
\hline & 1 & 2 & 3 & & \\
\hline 10 & 10.5 & 10.2 & 11.2 & 10.63 & 0.51 \\
\hline 30 & 30.3 & 31 & 30.5 & 30.60 & 0.36 \\
\hline 50 & 50.5 & 50.9 & 50 & 50.47 & 0.45 \\
\hline 70 & 70.8 & 70.5 & 71 & 70.77 & 0.25 \\
\hline 90 & 91.5 & 90.8 & 92 & 91.43 & 0.60 \\
\hline 110 & 112.2 & 114.6 & 113.5 & 113.43 & 1.20 \\
\hline 130 & 137.6 & 138 & 138.5 & 138.03 & 0.45 \\
\hline 200 & 210.3 & 211 & 210.6 & 210.63 & 0.35 \\
\hline 250 & 260.5 & 255.9 & 255.5 & 257.30 & 2.78 \\
\hline 300 & 317.5 & 310.5 & 311.7 & 313.23 & 3.74 \\
\hline
\end{tabular}

Data pada tabel 5 merupakan hasil pengujian pembacaan jarak benda yang menunjukkan semakin jauh jarak benda maka hasil pembacaan sensor semakin melemah. Nilai standar deviasi pada tabel di atas menghasilkan nilai distribusi yang kecil pada jarak baca di bawah $70 \mathrm{~cm}$ dengan selisih jarak rata - rata dengan jarak benda sebesar $0,77 \mathrm{~cm}$. Pada jarak benda di atas $90 \mathrm{~cm}$ hasil pembacaan jarak menghasilkan selisih jarak rata - rata dengan jarak benda yang sebenarnya semakin jauh dan standar deviasi yang semakin besar. Salah satu tantangan dalam perencanaan jalur untuk robot otomatis adalah ketidakpastian dalam lingkungan operasional [25]. Dimungkinkan adanya halangan yang tidak terprediksi yang dapat menghambat robot, pembacaan jarak yang tidak stabil berpotensi terjadi kesalahan pembacaan dan membuat robot gagal melakukan pengereman otomatis [26]. Robot USMAN menggunakan jarak $50 \mathrm{~cm}$ untuk mulai mendeteksi halangan di sekitar robot, dan pada jarak $30 \mathrm{~cm}$ mulai dilakukan pengereman otomatis agar robot tidak menabrak.

\subsection{Penghitungan Waktu Sterilisasi}

Perhitungan waktu sterilisasi dilakukan untuk mengetahui waktu yang dibutuhkan robot USMAN untuk proses sterilisasi luasan tertentu dari bidang lantai masjid agar pengguna dapat menjadwalkan waktu mulai sterilisasi, sehingga proses sterilisasi dapat selesai sebelum memasuki waktu salat berjamaah berikutnya. Perhitungannya adalah sebagai berikut:

Kecepatan gerak lurus

Waktu untuk berbelok $180^{\circ}$

$$
\begin{aligned}
& =5 \mathrm{~cm} / \text { detik } \\
& =3 \mathrm{~m} / \text { menit } \\
& =1 / 3 \text { menit } / \text { belokan }
\end{aligned}
$$

Robot mempunyai lebar $100 \mathrm{~cm}$ dan setiap bergerak robot menyapu luasan $100 \mathrm{~cm}$.

Waktu untuk gerak lurus = panjang lantai / kecepatan gerak lurus $\mathrm{x}$ lebar lantai

Waktu untuk berbelok = jumlah belokan $\mathrm{x}$ waktu untuk berbelok

Waktu sterilisasi $\quad=$ Jumlah waktu untuk gerak lurus + Jumlah waktu untuk berbelok

Dari data di atas didapat rumus seperti ditunjukkan pada Persamaan 3.

$$
\text { Waktu sterilisasi }=\frac{(\text { panjang lantai } \times \text { lebar lantai })+(\text { lebar lantai }-1)}{3}
$$

Di mana (Waktu Sterilisasi) adalah waktu yang dibutuhkan untuk melakukan proses sterilisasi. (panjang lantai) adalah jarak dinding kiri dan kanan masjid dan (lebar lantai) adalah jarak dinding depan dan belakang masjid. Untuk jumlah belokan yang terjadi adalah sejumlah lebar lantai dalam meter dikurangi 1 (lebar lantai - 1). Penjumlahan dari keduanya dibagi 3 yaitu kecepatan gerak robot 3 meter/menit.

Untuk sterilisasi bidang lantai masjid dengan ukuran 10 x 10 meter, dibutuhkan waktu sebagai berikut:

Waktu sterilisasi

$$
\begin{aligned}
& =((10 \times 10)+(10-1)) / 3 \\
& =36,3 \text { menit }
\end{aligned}
$$


Dari perhitungan di atas dapat diketahui waktu yang dibutuhkan untuk melakukan proses sterilisasi lantai masjid menggunakan USMAN, sehingga pengguna dapat menentukan waktu mulai sterilisasi sesuai luasan bidang lantai masjid. Apabila luasan bidang lantai masjid berukuran $10 \mathrm{x} 10 \mathrm{~m}$, maka proses sterilisasi dapat dimulai minimal 36,3 menit sebelum waktu salat berikutnya.

\subsection{Pembahasan}

Dari pengujian di atas menunjukkan bahwa fungsi aplikasi USMAN dapat bekerja dengan baik. Aplikasi pada robot USMAN dapat terhubung dengan aplikasi mobile USMAN menggunakan bluetooth. Pengguna dapat melakukan perintah gerakan manual seperti maju dan berbelok dengan menekan tombol pada aplikasi mobile USMAN dan robot bergerak sesuai perintah tersebut. Pengguna juga dapat merekam gerakan robot sesuai dengan keadaan ruangan masing-masing masjid, kemudian rekaman tersebut dapat dijalankan berulang kali. Pengguna juga dapat mengatur jadwal kerja robot USMAN agar dapat memulai proses sterilisasi sesuai waktu yang diinginkan, sehingga penggunaan robot USMAN menjadi lebih efektif, marbot masjid tidak perlu mengendalikan robot UMSAN sepanjang waktu.

Kebaruan dalam penelitian ini selain penerapan sinar UVC untuk proses sterilisasi pada robot USMAN, juga pada penerapan Algoritma PID (Proportional-Integral-Derivative) pada sistem kendali robot USMAN dengan ukuran memanjang $100 \mathrm{~cm}$ dengan 2 roda penggerak yang sulit dikendalikan secara konvensional dengan teknik set-timer. Penggunaan Algoritma PID dengan dukungan sensor rotary encoder dan sensor kompas dapat meningkatkan ketepatan jarak tempuh robot USMAN sesuai set point yang direncanakan. Kesalahan gerak robot dapat diakibatkan oleh lantai yang bergelombang maupun roda selip. Penerapan Algoritma PID menghasilkan gerakan robot yang lebih tepat dan stabil. Pada pengujian ketepatan jarak tempuh, kesalahan terbesar hanya 3,2 cm dengan standar deviasi terbesar 0,44 pada jarak tempuh $1.000 \mathrm{~cm}$, lebih baik daripada teknik set-timer dengan kesalahan terbesar mencapai $15.5 \mathrm{~cm}$ dan standar deviasi terbesar 10.46 pada jarak yang sama. Artinya jarak yang ditempuh robot USMAN dengan Algoritma PID lebih mendekati jarak yang diperintahkan pengguna.

Selain jarak tempuh, kelurusan gerakan robot juga meningkat pada jarak tempuh jauh maupun dekat, dengan selisih jarak posisi akhir terbesar hanya $2,2 \mathrm{~cm}$ dari garis lurus dengan standar deviasi terbesar 0,35 pada jarak tempuh $1.000 \mathrm{~cm}$. Algoritma PID membuat gerakan roda kanan dan kiri menjadi lebih sesuai, apabila salah satu roda selip maka akan dikoreksi secara otomatis di sepanjang perjalanan robot menuju set point. Ketepatan sudut manuver berbelok robot USMAN juga mengalami peningkatan dengan standar deviasi 0,29 dan selisih derajat terbesar hanya $0.5^{\circ}$, lebih baik daripada menggunakan settimer dengan selisih terbesar mencapai $2,5^{\circ}$ dan standar deviasi terbesar 1,80. Pendeteksian benda di sekitar robot menjadi penting untuk mengaktifkan sistem pengereman otomatis agar robot tidak menabrak. Penggunaan sensor jarak pada robot USMAN diterapkan pada jarak $50 \mathrm{~cm}$ untuk mulai mendeteksi benda dan jarak $30 \mathrm{~cm}$ untuk mulai pengereman otomatis, karena sesuai hasil pengujian pada jarak di bawah 70 $\mathrm{cm}$ ketepatan pembacaan sensor lebih akurat.

Untuk proses sterilisasi menggunakan sinar UVC tergantung pada dosis energi radiasi dan lama paparan, USMAN menerapkan kecepatan gerak $5 \mathrm{~cm} /$ detik. Dengan ukuran lebar bidang paparan $30 \mathrm{~cm}$ maka setiap $1 \mathrm{~cm}$ lantai terpapar selama 6 detik. Proses sterilisasi lantai dengan ukuran $10 \mathrm{~m} \times 10 \mathrm{~m}$ membutuhkan waktu 36,3 menit, sehingga pengguna dapat memulai proses sterilisasi sesuai dengan kebutuhan waktu sterilisasi. Untuk ukuran lantai masjid yang lebih luas, pengguna dapat menggunakan robot USMAN dengan waktu lebih lama, maupun dapat menggunakan lebih dari 1 robot USMAN yang dijalankan secara bersamaan pada bidang lantai yang berbeda.

\section{Kesimpulan}

Dari hasil pengujian dan analisa didapat kesimpulan bahwa semua fungsi aplikasi USMAN dapat berjalan dengan baik, robot USMAN dapat dikendalikan dengan remote, dapat merekam gerakan dan dapat diatur jadwal kerja untuk berjalan otomatis. Penerapan Algoritma PID (Proportional-Integral-Derivative) dengan nilai $K p=10, K i=0$ dan $K d=100$ yang dikombinasikan dengan sensor kompas, sensor rotary encoder dan sensor jarak terbukti dapat meningkatkan kinerja sistem kendali robot USMAN dibandingkan dengan penggunaan teknik set-timer. Hasil pengujian menunjukkan peningkatan kinerja kendali robot USMAN dengan nilai standar deviasi tertinggi untuk ketepatan jarak tempuh menurun dari 10.46 menjadi 0,44, nilai standar deviasi tertinggi untuk kelurusan gerak menurun dari 10.21 menjadi 0,35 dan nilai standar deviasi tertinggi untuk ketepatan manuver berbelok menurun dari 1,80 menjadi 0,29. Nilai standar deviasi yang mengalami penurunan menunjukkan bahwa ketepatan gerakan robot meningkat, sehingga posisi akhir gerakan robot lebih sesuai dengan instruksi pengguna. Pembacaan halangan dengan sensor jarak akurat di bawah $70 \mathrm{~cm}$, sehingga USMAN menerapkan nilai pembacaan halangan pada jarak $50 \mathrm{~cm}$ dan $30 \mathrm{~cm}$ untuk fitur pengereman otomatis agar robot tidak menabrak. Proses sterilisasi lantai masjid dengan ukuran 10 m x 10 m membutuhkan waktu 36,3 menit. 
Pengguna dapat memulai proses sterilisasi sesuai dengan waktu yang dibutuhkan agar proses sterilisasi dapat selesai sebelum masuk waktu salat selanjutnya. Penelitian ini dapat menjadi pilot project penelitian lainnya, terutama pengembangan ke arah penerapan mode autonomous system pada robot sterilisasi lantai.

\section{Daftar Pustaka}

[1] Yuliana, "Corona virus diseases (Covid -19); Sebuah tinjauan literatur," WELLNESS Heal. Mag., vol. 2, no. February, pp. 187 - 192, 2020.

[2] A. Jumhan, "MENGHIDUPKAN SHALAT BERJAMAAH DI MASJID NURUL JANNAH SERIKEMBANG III KECAMATAN PAYARAMAN KABUPATEN OGAN ILIR,” J. Ilm. Pengabdi. Kpd. Masy., vol. 53, no. 9, pp. 98-102, 2019.

[3] A. D. Elisanti, E. T. Ardianto, N. C. Ida, and E. Hendriatno, "Effectiveness Of Uv And Alcohol 70\% Exposure To Total Bacteria Of Folding Money Circulating During The Pandemic Covid-19," J. Ris. Kefarmasian Indones., vol. 2, no. 2, pp. 113-121, 2020.

[4] M. H. Al-Sayah, "Chemical disinfectants of COVID-19: An overview," J. Water Health, vol. 18, no. 5, pp. 843-848, 2020, doi: 10.2166/wh.2020.108.

[5] F. A. Juarez-Leon, A. G. Soriano-Sanchez, M. A. Rodriguez-Licea, and F. J. Perez-Pinal, "Design and implementation of a germicidal UVC-LED lamp," IEEE Access, vol. 8, pp. 1-1, 2020, doi: 10.1109/access.2020.3034436.

[6] M. Buonanno et al., "Germicidal efficacy and mammalian skin safety of 222-nm UV light," Radiat. Res., vol. 187, no. 4, pp. 483-491, 2017, doi: 10.1667/RR0010CC.1.

[7] N. Storm et al., "Rapid and complete inactivation of SARS-CoV-2 by ultraviolet-C irradiation," pp. 1-7, 2020.

[8] A. Mardon, N. Lum, and M. Xiao, COVID-19 and Robotics. Edmonton: Golden Meteorite Press, 2020 .

[9] M. Lamatenggo, I. Wiranto, and W. Ridwan, "Perancangan Balancing Robot Beroda Dua Dengan Metode Pengendali PID Berbasis Arduino Nano," Jambura J. Electr. Electron. Eng., vol. 2, no. 2, pp. 39-43, 2020, doi: 10.37905/jjeee.v2i2.6906.

[10] M. J. C. Manullang, M. K. D. Hardhienata, and K. Priandana, "Kendali Robot Beroda Otonom dengan Inverse Kinematics," J. Ilmu Komput. dan Agri-Informatika, vol. 7, no. 1, pp. 62-73, 2020, doi: 10.29244/jika.7.1.62-73.

[11] F. Z. Ramdhani, D. R. Riyanto, and D. Desriyanti, "Electronic Sterilization of Tableware Using Ultraviolet Light Radiation," JEEE-U (Journal Electr. Electron. Eng. UMSIDA), vol. 4, no. 1, pp. 70-79, 2020, doi: 10.21070/jeeeu.v4i1.316.

[12] M. Guettari, I. Gharbi, and S. Hamza, "UVC disinfection robot," Environ. Sci. Pollut. Res., 2020, doi: https://doi.org/10.1007/s11356-020-11184-2.

[13] A. Fikri, "Kemiripan Arsitektur Tiang Masjid Ampel Karangasem Bali dengan Masjid Agung Demak," in Seminar Ikatan Peneliti Lingkungan Binaan Indonesia (IPLBI) 1, 2017, pp. A351A354, doi: 10.32315/sem.1.a351.

[14] Y. N. Hilal, S. Heranurweni, and A. Kurniawan N, "Rancang Bangun Robot Pemadam Api Beroda Dengan Navigasi Sensor Kompas Berbasis Atmega 128,” Elektrika, vol. 9, no. 1, pp. 9-12, 2017, doi: 10.26623/elektrika.v9i1.1108.

[15] N. Sudin, I. Djufri, and M. Umar, "Rancang Bangun Sistem Pengontrol Lampu Rumah Berbasis Mikrokontroler Arduino Uno Menggunakan Smartphone," J. Ilm. Ilk. - Ilmu Komput. Inform., vol. 3, Jul. 2020, doi: 10.47324/ilkominfo.v3i2.102.

[16] E. Parliament et al., "Signify and Boston University validate effectiveness of Signify's UV-C light sources on inactivating the virus that causes COVID-19," Boston, 2020.

[17] S. S. Dheeban, D. V. Harish, A. Hari Vignesh, and M. Prasanna, "Arduino Controlled Gesture Robot," 2018 IEEE 4th Int. Symp. Robot. Manuf. Autom. ROMA 2018, pp. 1-6, 2018, doi: 10.1109/ROMA46407.2018.8986730.

[18] B. Winarno and M. W. P. Pratama, "Pengendalian Gerak Robot Penghindar Halangan Menggunakan Citra dengan Kontrol PID,” JEECAE (Journal Electr. Electron. Control. Automot. Eng., vol. 1, no. 1, pp. 25-30, 2017, doi: 10.32486/jeecae.v1i1.8.

[19] A. Mappa and M. D. T. Sogen, "Rancang Bangun Prototype Sistem Pengendalian Kecepatan Dan Pengereman Menggunakan Sensor Jarak,” Electro Luceat, vol. 5, no. 2, pp. 48-61, 2019, doi: 10.32531/jelekn.v5i2.153.

[20] D. Diana and J. Al-Rasyid, "Implementasi Sensor Compas HMC5883L Terhadap Gerak Robot Micromouse dengan Menggunakan Algoritma PID," J. Tek. Elektro ITP, vol. 6, no. 2, pp. 120124, 2017, doi: 10.21063/jte.2017.3133616. 
[21] D. Irawan and P. Perdana SS, "Kontrol Motor Brushless DC (BLDC) Berbasis Algoritma AI PID," J. Tek. Elektro dan Komputasi, vol. 2, no. 1, pp. 41-48, 2020, doi: 10.32528/elkom.v2i1.3146.

[22] N. Nafi'iyah, "Perbandingan Modus , Median , K _ Standar Deviasi, Iterative , Mean Dan Otsu Dalam Thresholding," J. SPIRIT, vol. 8, no. 2, pp. 31-36, 2016.

[23] N. Kadir, J. Febriana, and E. P. Rahayu, "Penerapan ISO 9126 Dalam Pengujian Kualitas Perangkat Lunak pada E-book," Matics, vol. 11, no. 1, pp. 9-13, 2019.

[24] M. A. Habib, M. S. Alam, and N. H. Siddique, "Optimizing Coverage Performance of Multiple Random Path-planning Robots," Paladyn, J. Behav. Robot., vol. 3, no. 1, pp. 11-22, 2012, doi: 10.2478/s13230-012-0012-5.

[25] I. Sung, B. Choi, and P. Nielsen, "On the training of a neural network for online path planning with offline path planning algorithms," Int. J. Inf. Manage., p. 102142, Jun. 2020, doi: 10.1016/j.ijinfomgt.2020.102142.

[26] A. Frobenius, E. Utami, and A. Nasiri, "Analysis of Speed Gablind App in Detecting ObstacleExperiment Results," in 2018 3rd International Conference on Information Technology, Information System and Electrical Engineering (ICITISEE), Nov. 2018, pp. 319-324, doi: 10.1109/ICITISEE.2018.8720964. 